\title{
The historical development of vegetation of foreshore mires beside humic lakes: different successional pathways under various environmental conditions
}

\author{
Danuta Drzymulska • Stanisław Kłosowski • \\ Paweł Pawlikowski • Piotr Zieliński • \\ Ewa Jabłońska
}

Received: 19 April 2012 /Revised: 6 September 2012/ Accepted: 30 September 2012/Published online: 20 October 2012

(C) The Author(s) 2012. This article is published with open access at Springerlink.com

\begin{abstract}
The historical development of the hydroseral vegetation of three humic lakes was studied. We applied a combination of methods to reconstruct the past vegetation (plant macroscopic remains, peat decomposition, sediment chemistry and radiocarbon dating). The contemporary environment of these lakes was assessed by vegetation and water chemistry analyses. The oldest foreshore sediments were formed 13075-12700 cal BP (Lake Suchar VI), 10115-9670 cal BP (Lake Suchar III) and 8747-8479 cal BP (Lake Widne). The differences in contemporary vegetation are reflected in the subfossil plant assemblages. From the beginning, poor fens and bogs occurred beside Lake Suchar III, moderately rich
\end{abstract}

Handling editor: Jasmine Saros

Electronic supplementary material The online version of this article (doi:10.1007/s10750-012-1334-3) contains supplementary material, which is available to authorized users.

D. Drzymulska ( $\bowtie)$

Department of Botany, Institute of Biology, University of Białystok, Świerkowa 20b, 15-950 Białystok, Poland e-mail: drzym@uwb.edu.pl

S. Kłosowski · P. Pawlikowski · E. Jabłońska Department of Plant Ecology and Environmental Conservation, Institute of Botany, University of Warsaw, Al. Ujazdowskie 4, 00-478 Warsaw, Poland

P. Zieliński

Department of Hydrobiology, Institute of Biology,

University of Białystok, Świerkowa 20b,

15-950 Białystok, Poland and poor fens were developed at Lake Suchar VI, while reedswamps and moderately rich fens occurred at Lake Widne. The foreshore vegetation changed over time but only within a restricted range, specific for each lake corresponding to the hydrochemical differences between the lakes. Lakes are classified as humic if some features are combined, such as the specific vegetation and water parameters. However, over the past few decades escalating climatic and anthropogenic changes could transform the character of these water bodies. The application of multidisciplinary methods permitted comparison of the development of three apparently similar lakes and identification of significant ecological differences.

Keywords Humic lake $\cdot$ Trophy $\cdot$ Peat $\cdot$ Subfossil vegetation $\cdot$ Contemporary hydroseral vegetation

\section{Introduction}

Nauman (1917) was the first to mention humic lakes in the scientific literature. Classifying lakes from the ecological point of view, he classified humic lakes as dystrophic. A few years later, Thienemann (1922) dividing lakes into groups introduced a new term for the humic/dystrophic lake-brown water lake. These three terms still now are regarded as synonyms in North and Central Europe. One of the most specific features of these water bodies is a presence of organic, dark brown, semi-liquid sediment called "dy." 
They are also characterized by catchments covered with peat and/or overgrown by coniferous forests, the presence of Sphagnum carpets in the vicinity of water bodies, the high content of weak humic acids (HS), low-calcium content, low $\mathrm{pH}$ (4.5-6.0), small algal biomass, poor taxonomic biodiversity, higher respiration than primary production (Salonen et al., 1983; Wetzel, 1983; Brönmark \& Hansson, 2005; Gąbka \& Owsianny, 2006). Low-pH values result from the large amounts of humic acids in the water (Kullberg et al., 1993). According to De Haan (1992), these substances alone flowing into lakes from catchment peat bogs are responsible for lake dystrophication.

Humic lakes are typical of the boreal zone (Ojala \& Salonen, 2001). In northeastern Poland, they occur in Wigry National Park (WNP), where climate and vegetation cover are similar to the conditions in Scandinavia. In Polish, they are known as suchary (Stangenberg, 1936). These small brown water lakes (0.5-3 ha) are closed systems, lacking inflows and outflows, and are surrounded by forests. Floating mats formed by the roots and rhizomes of vascular plants (Scheuchzeria palustris, Cyperaceae, Ericaceae) and Sphagnum mosses are the characteristic feature of these lakes. Suchary lakes have been studied in detail using hydrobiological methods, which have confirmed their dystrophic status (Górniak et al., 1999; Górniak, 2006; Hutorowicz et al., 2006). Less attention, however, has been focused on past and present foreshore vegetation. Sobotka (1967) studied the overgrown zones of suchary in the 1960s and described plant communities and probable directions of their succession.

Humic lakes are protected in the European Union and registered in Appendix of the Habitat Directive as "Natural dystrophic lakes and ponds" (Anonymous, 2007). Lakes with different vegetation and variable habitat conditions, especially $\mathrm{pH}$, have been described even within one country as "dystrophic" or "humic" both previously (Sobotka, 1967) and currently (Gąbka et al., 2004; Górniak, 2006; Chmiel, 2009; Poniewozik et al., 2011; Zieliński et al., 2011). Thus, it would be very important to clarify terms concerning humic lakes and to classify them. It is especially important because of the uniqueness of these ecosystems and their degradation. Humic lakes are very sensitive to any environmental changes. In an era of progressive climatic, anthropogenic, hydrometeorological and ecological changes, the stressors facing of humic lakes seem to be especially important.

This article focuses on three humic lakes in WNP. Lake Suchar III is characterized by a typical floating mat composed of extremely poor fen and bog vegetation (sensu Sjörs, 1952). The two other lakes, Lake Suchar VI and Lake Widne, have floating mats with both peat mosses and vegetation associated with mesotrophic and eutrophic lakes (sensu Sjörs, 1952). Approximately 50 years after Sobotka's research, sediment cores were taken to supply macrofossils information on past limnological changes, thus providing a historical context for the contemporary ecological-limnological systems.

Thus, the aims of our article are to: (i) identify and compare the developmental pathways of lakeside vegetation (hydroseres) in the past; (ii) conclude how present plant communities correspond to subfossil vegetation; (iii) decide on the strength of the subfossil and contemporary environmental data if the lakes studied are humic water bodies and to determine where the border is between humic and non-humic lakes.

\section{Materials and methods}

Study sites

The Wigry National Park (WNP) is located in the Lithuanian Lakeland area (Kondracki, 1994), in northeastern Poland (Fig. 1). The relief of the area was formed by the Weichselian (Vistulian) Glaciation (Marks, 2002). A number of kames, eskers and frontal moraines occur in the northern and middle part of the WNP. The southern part is covered with an extensive sandur with primary glacial relief which has been strongly transformed (Ber, 2009). The climate of this area is transitional temperate continental.

The dystrophic lakes of the WNP are located in the vicinity of the Wigry Lake, one of the biggest and deepest lakes in Poland (area $21.63 \mathrm{~km}^{2}$, max. depth $74.2 \mathrm{~m}$ ). Lake Suchar III (SIII in following text) and Lake Suchar VI (SVI in following text) are situated NW of Lake Wigry and Lake Widne (JW in following text)—next to the southern shore of Lake Wigry (Fig. 1). The geographical position and parameters of the investigated lakes are given in Table 1. 
Fig. 1 The location of studied lakes in Wigry National Park (NE Poland). 1 location of cores, 2 park border
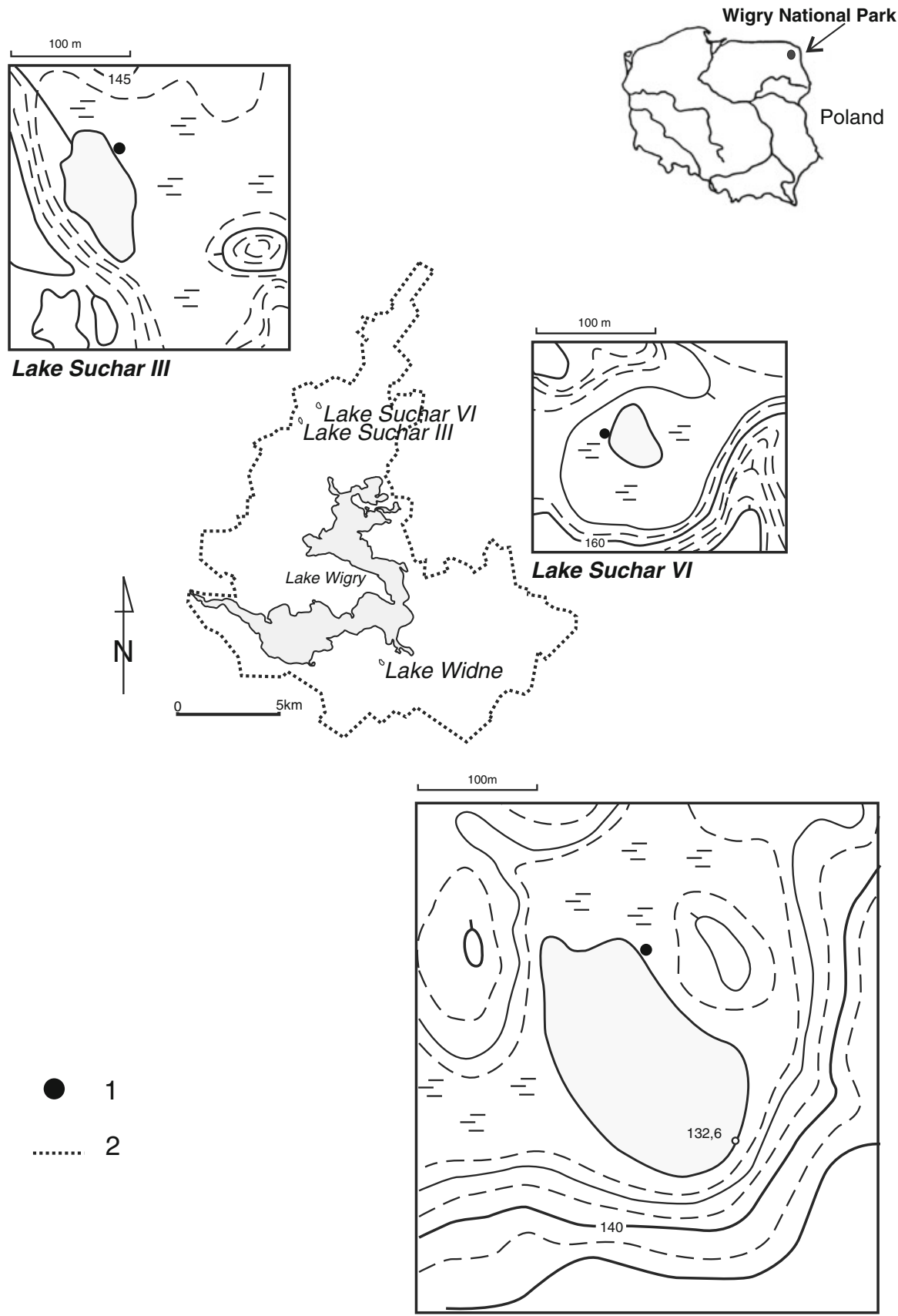

Lake Widne
Coring and sampling

The material for the study was collected in the foreshore of three dystrophic lakes (Fig. 1) using a Russian sampler (diameter $8 \mathrm{~cm}$ ). Single cores were drilled in the zone of the firm (non-quaking) mire.
The length of cores was as follows: from SIII$670 \mathrm{~cm}$, from SVI $-780 \mathrm{~cm}$ and from JW-90 cm. The cores were divided into segments of $5 \mathrm{~cm}$. Samples were cut out from cores. The entire sediment sequence was used for analysis of plant macrofossils. Chemical analyses of sediments and 
Table 1 Location and parameters of studied lakes (according to Górniak (2006))

\begin{tabular}{lllllll}
\hline Lake & Latitude & Longitude & Area (ha) & Max. depth $(\mathrm{m})$ & Catchment (ha) & Catchment/lake area rate \\
\hline Suchar III & $54^{\circ} 05^{\prime} 19^{\prime \prime} \mathrm{N}$ & $23^{\circ} 01^{\prime} 18^{\prime \prime} \mathrm{E}$ & 0.44 & 4.0 & 32.0 & 72.72 \\
Suchar VI & $54^{\circ} 06^{\prime} 00^{\prime \prime} \mathrm{N}$ & $23^{\circ} 01^{\prime} 42^{\prime \prime} \mathrm{E}$ & 0.31 & 2.0 & ne & ne \\
Widne & $54^{\circ} 00^{\prime} 44^{\prime \prime} \mathrm{N}$ & $23^{\circ} 07^{\prime} 25^{\prime \prime} \mathrm{E}$ & 2.04 & 5.7 & 16.6 & 8.13 \\
\hline
\end{tabular}

radiocarbon dating were conducted for selected sediment samples.

Analysis of macrofossil plant remains

For plant macrofossils, the material was rinsed with deionized water with an addition of $10 \% \mathrm{KOH}$. Next the suspensions were boiled, washed out on $0.2 \mathrm{~mm}$ sieve and placed in Petri dishes. At first, generative remains (fruits, seeds and catkin scales) from every sample were picked out identified under a stereoscopic microscope at magnification of 10-100×. Vegetative plant remains (roots, epidermis, periderm, rhizoderm, leaves and stems, wood) were identified with a light microscope at $200-400 \times$ magnification. Only remains with cellular structure were taken into account. The remains were identified with the help of Mauquoy \& van Geel (2007), Hedenäs (2003), Rybníček \& Rybníčková (1974) and Katz et al. (1965). The botanical composition, based on the proportion of each taxon's tissues in the total tissue mass, was estimated. Generative remains (e.g. seeds, fruits and catkin scales) were counted. Diagrams of vegetative macrofossils were based on percentage data. Peat units were distinguished according to Tołpa et al. (1967). A few units absent in the mentioned system were also described. In dy samples, the presence of remains was only noted. The obtained results were presented as diagrams constructed with the software package POLPAL (Walanus \& Nalepka, 1999). Macrofossils were grouped according to classes of vegetation based on Matuszkiewicz (2001). For diagrams we defined biostratigraphic zones-plant macrofossil zones.

Analysis of peat decomposition

The peat decomposition degree was determined for each peat sample by microscope. This parameter was based on humus/peat ratio in sample, where "peat" denotes the sum of humus and non-decayed parts. According to Obidowicz (1990), peat could be divided into: slightly decomposed (decomposition up to $25 \%$ ), medium decomposed (30-40\%), strongly decomposed (45-60\%) and humopeat $(65 \%$ and up). This parameter provides information about the humidity of the mire surface during the peat forming process in the past. The decrease of peat decomposition degree could be an indicator of the ground water table rise. The results were presented as histograms drawn with POLPAL software (Walanus \& Nalepka, 1999).

\section{Radiocarbon dating}

${ }^{14} \mathrm{C}$ samples were prepared by manual selection of plant remains according to Kilian et al. (2000) and dated by AMS both in the Poznan Radiocarbon Laboratory (Poz) and in the Gliwice Radiocarbon Laboratory (GdA). The radiocarbon age of the samples was calibrated with the OxCal 4.1 online software (Bronk Ramsey, 2009). Chronology for the Holocene was presented according to Mangerud et al. (1974), with calibration of chronozone boundaries (Walanus \& Nalepka, 2010). Periodization of the Late Glacial by Litt et al. (2001) was used. Average accumulation rates were calculated based on the middle values of two calibrated datings of each profile and presented in Figs. 2, 3 and 4. They supply approximate information about rate of sediment deposition. The radiocarbon datings are given in detail in Table 2.

Chemical analyses of sediments

Analyses were performed on sediment sections with different plant remains characteristics. There were altogether 16 sediment samples selected for chemical property determination: SIII-5 samples (depths: 45, 405, 565, 575, and $645 \mathrm{~cm}$ ), SVI-7 samples (depths: $245,535,545,635,675,685$, and $775 \mathrm{~cm})$ and JW-4 samples (depths: 10, 20, 40 and $70 \mathrm{~cm}$ ).

The chemical characteristics of sediments were based on the measurement of loss-on-ignition (LOI), 


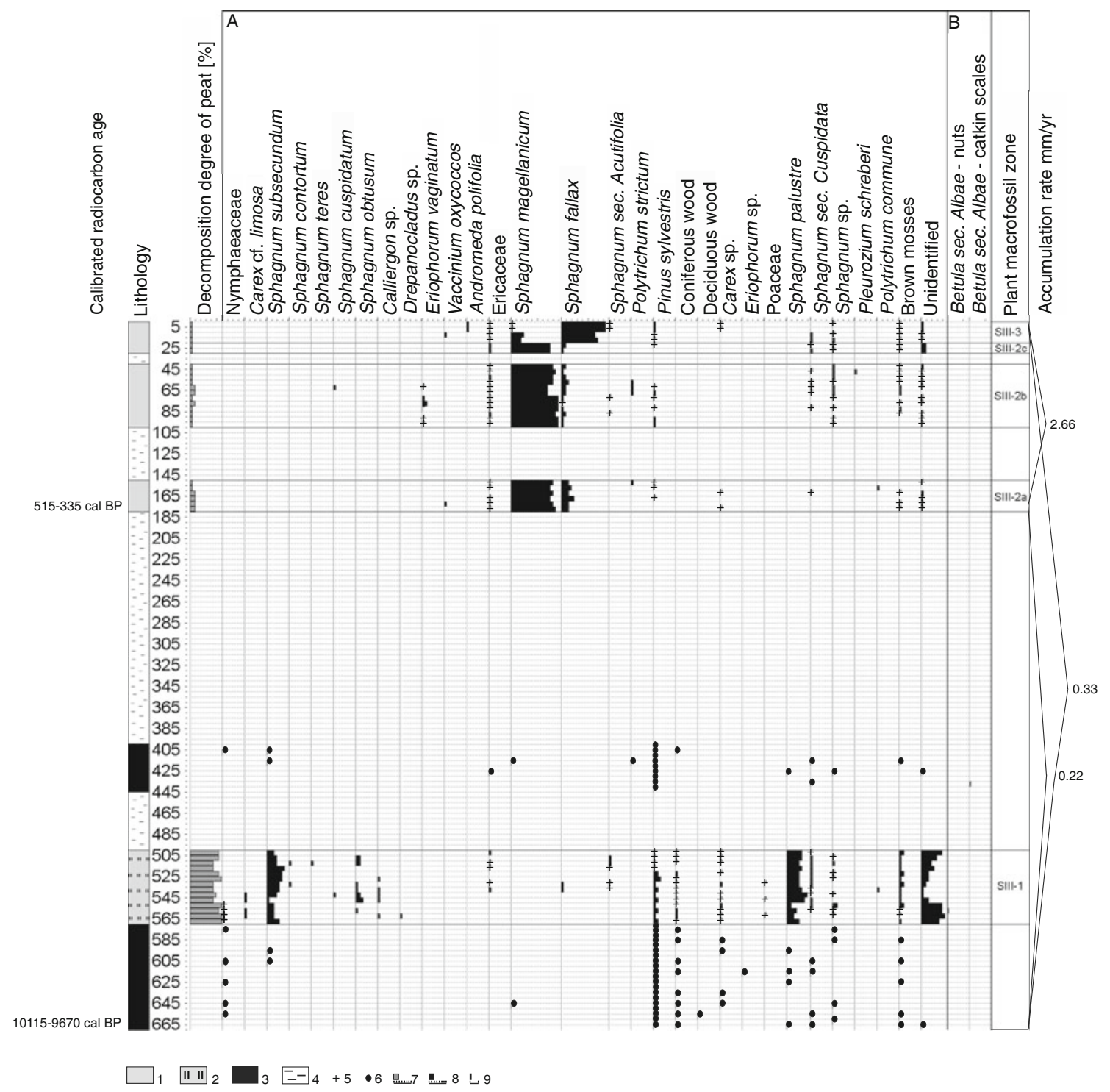

Fig. 2 Lake Suchar III. Diagram of the macroscopic plant remains and decomposition degree of peat. A vegetative remains, B generative remains, 1 Sphagnum peat, 2 poor fen

organic carbon content, Kjeldahl Nitogen $(\mathrm{KN})$ and calcium carbonate content (Table 3). Sediment samples were dried at $105^{\circ} \mathrm{C}$, after removal of all particulate organic matter greater than $1 \mathrm{~cm}$ in length. Water content was calculated after drying for $24 \mathrm{~h}$ at $105^{\circ} \mathrm{C}\left(\mathrm{LOI}_{105}\right)$. All samples were tested for carbonates by treating with $10 \% \mathrm{HCl}$ and observing effervescence. Samples with observed effervescence were analysed with the calcium carbonate volumetric method using a Scheibler calcimeter (Allison \&
Sphagnum peat, 3 dy, 4 water, 5 minimal amount, 6 presence, 7 peat decomposition $(10 \%), 8$ vegetative macrofossils (10\%), 9 one piece

Moodie, 1965). Total carbon (TC) was determined by incineration of the samples in $550^{\circ} \mathrm{C}$ for $5 \mathrm{~h}$ in a common furnace (Howard \& Howard, 1990). Total carbon for sediments containing carbonates was analysed by dichromate oxidation according to Nelson \& Sommers (1996). KN was determined on 0.25-1.0 g of sediment samples according to Bremner \& Mulvaney (1982). Organic matter, organic C, carbonates and $\mathrm{KN}$ values were calculated as percentages of the furnace-dried $105^{\circ} \mathrm{C}$ weight. The discriminant 


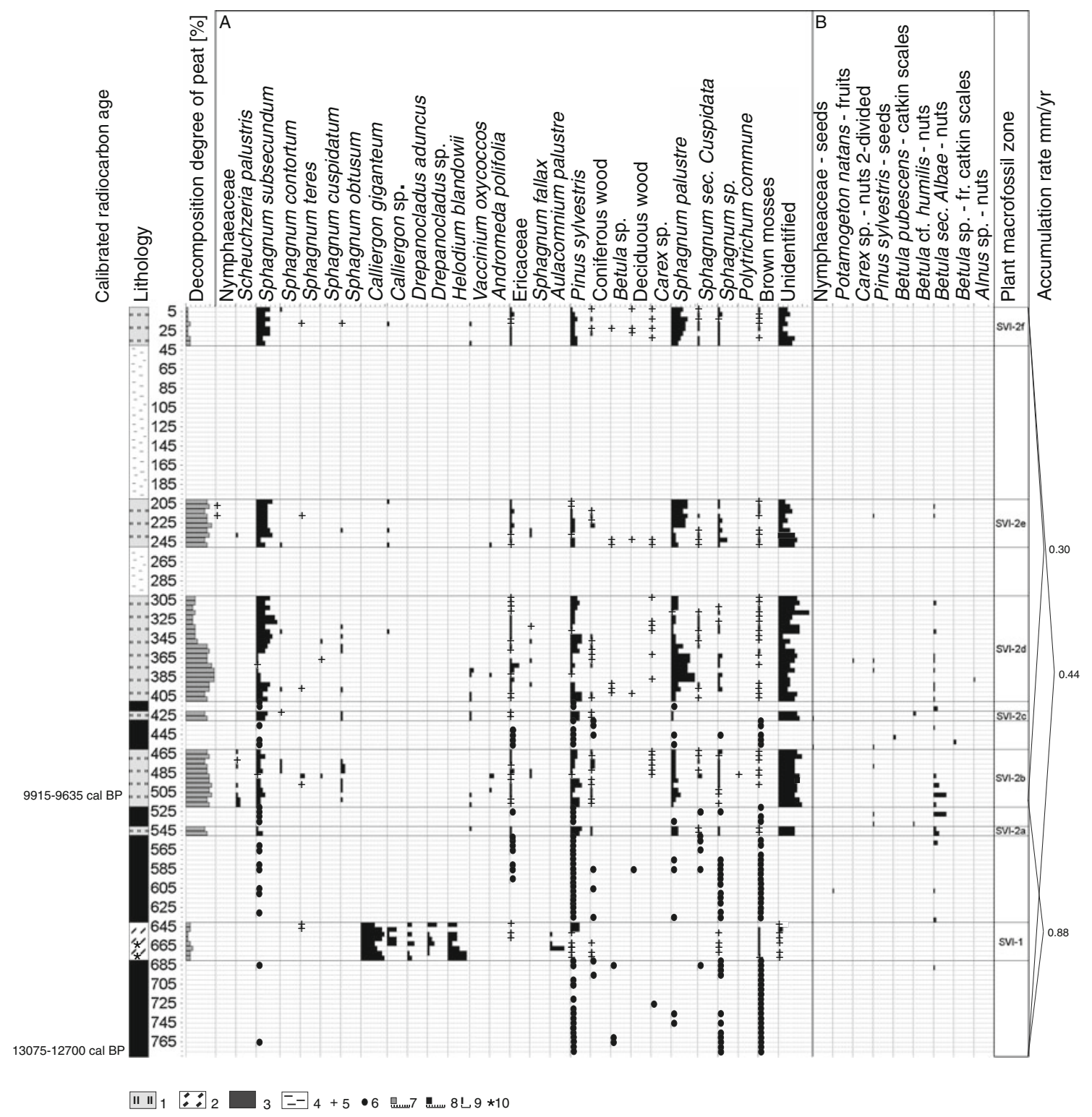

Fig. 3 Lake Suchar VI (SVI). Diagram of the macroscopic plant remains and decomposition degree of peat. A vegetative remains, B generative remains, 1 poor fen Sphagnum peat,

analysis of chemical parameters of sediments was made with the Statgraphics (5.0) software.

Lake water analyses

Lake surface water samples were transferred to $1,000 \mathrm{ml}$ plastic containers. Electrical corrected conductivity $\left(\mathrm{EC}_{\text {corr. }}\right)$ (Sjörs, 1952) and $\mathrm{pH}$ values were
2 brown moss peat, 3 dy, 4 water, 5 minimal amount, 6 presence, 7 peat decomposition $(10 \%), 8$ vegetative macrofossils (10\%), 9 one piece, $10 \mathrm{CaCO}_{3}$ presence

measured immediately using a portable device. Half of the each water sample $(500 \mathrm{ml})$ was preserved (stabilized?) by the addition of $1 \mathrm{ml}$ concentrated $\mathrm{H}_{2} \mathrm{SO}_{4}$ for total $\mathrm{Fe}$ (spectrophotometrically by the rhodanate method). Chemical oxygen demand (COD) was determined, on the day of sampling, as consumption of $\mathrm{KMnO}_{4}$ in acid medium. COD- $\mathrm{KMnO}_{4}$ is an indicator of dissolved organic matter (DOM) content. 
Fig. 4 Lake Widne (JW). Diagram of the macroscopic plant remains and decomposition degree of peat. A vegetative remains, B generative remains, 1 poor fen Sphagnum peat, 2 sedgereed peat, 3 sedge-

Sphagnum peat, 4 minimal amount, 5 peat decomposition (10\%), 6 vegetative macrofossils $(10 \%), 7$ one piece

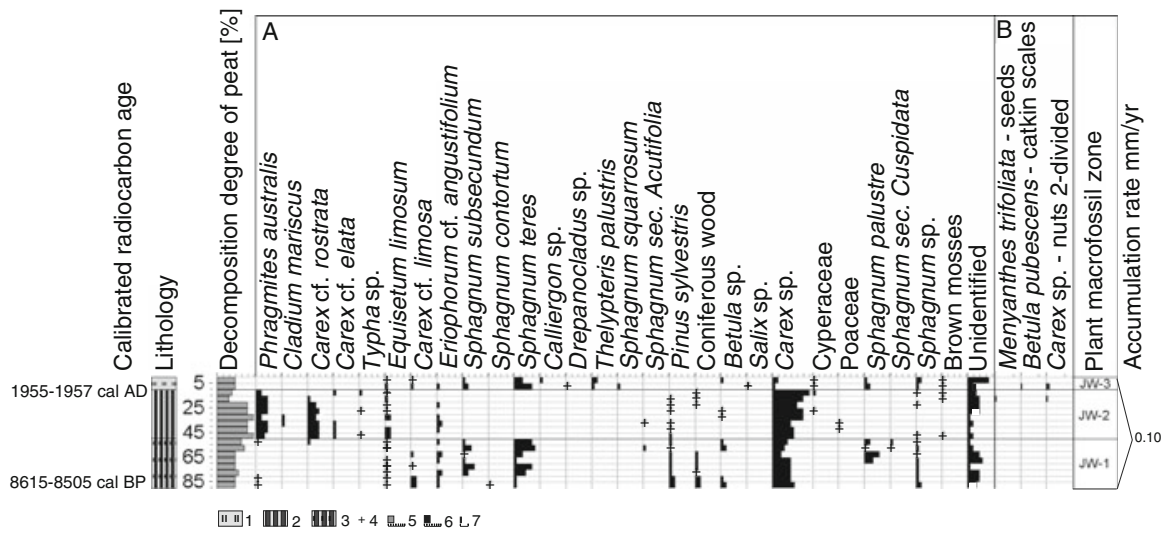

Table 2 Radiocarbon datings from studied profiles

\begin{tabular}{llllcl}
\hline Core & $\begin{array}{l}\text { Sample } \\
\text { depth }(\mathrm{cm})\end{array}$ & Sample composition & $\begin{array}{l}\text { Laboratory } \\
\text { number }\end{array}$ & ${ }^{14} \mathrm{C}$ age & $\begin{array}{l}\text { Cal year BP and/or AD according } \\
\text { to OxCal } 4.1 \text { online software } \\
\text { Bronk Ramsey }(2009) \\
95.4 \% \text { probability }\end{array}$ \\
\hline SIII & 663 & Sphagnum remains & GdA-2377 & $8,785 \pm 30 \mathrm{BP}$ & $10115-9670 \mathrm{cal} \mathrm{BP}$ \\
SIII & 173 & Sphagnum remains & GdA-2380 & $405 \pm 20 \mathrm{BP}$ & $1435-1615 \mathrm{cal} \mathrm{AD}$ \\
& & & & & $515-335 \mathrm{cal} \mathrm{BP}$ \\
SVI & 779 & Brown mosses remains & GdA-2379 & $11005 \pm 35 \mathrm{BP}$ & $13075-12700 \mathrm{cal} \mathrm{BP}$ \\
SVI & 505 & Sphagnum remains & GdA-2378 & $8,780 \pm 30 \mathrm{BP}$ & $9915-9635 \mathrm{cal} \mathrm{BP}$ \\
JW & 85 & Sphagnum remains & Poz-30007 & $7,790 \pm 50 \mathrm{BP}$ & $8615-8505 \mathrm{cal} \mathrm{BP}$ \\
JW & 13 & Sphagnum remains & GdA-2381 & $104.13 \pm 0.24 \mathrm{pMC}$ & $1955-1957 \mathrm{cal} \mathrm{AD}$
\end{tabular}

In the remaining water, $\mathrm{Ca}^{2+}$ (measured with a flame spectrophotometer JENWAY PFP7) and $\mathrm{Mg}^{2+}$ (determined with an atomic absorption spectrophotometer UNICAM 939) concentrations were measured. All the determinations of water chemistry were carried out by methods described by Hermanowicz et al. (1999).

\section{Analysis of present day vegetation}

The vegetation around dystrophic lakes forms concentric, physiognomically differing zones: (1) lake vegetation, (2) quaking (floating) mire, (3) firm (nonquaking) mire and (4) pine woodland. In each zone, a phytosociological relevé $(3 \times 3 \mathrm{~m}$ in non-forest vegetation, $10 \times 10 \mathrm{~m}$ in woodlands) was made using the classic Braun-Blanquet (1951) method. The plots were arranged in transects ( 8 transects in total: 2 transects in SIII and 3 transects in SVI and JW, respectively; in some cases lake outermost zones of vegetation were totally absent).
The nomenclature of vascular plants follows Mirek et al. (2002) and of mosses Ochyra et al. (2003). The similarity of the studied plots was analysed by detrended correspondence analysis (DCA) (CANOCO for Windows Version 4.0, Ter Braak \& Šmilauer, 1998).

\section{Results}

Lithology and age of sediments. Subfossil vegetation

The studied cores differed in thickness and typology of sediments. In SIII and SVI profiles, dy-type sediment, as well as water gaps, was noted (Figs. 2, 3, respectively). Most of the peat material comprised vegetative remains such as tissues of vascular plants and remains of mosses-leaves, branches and stems. Fruits and seeds were found sporadically, and only birch nuts 


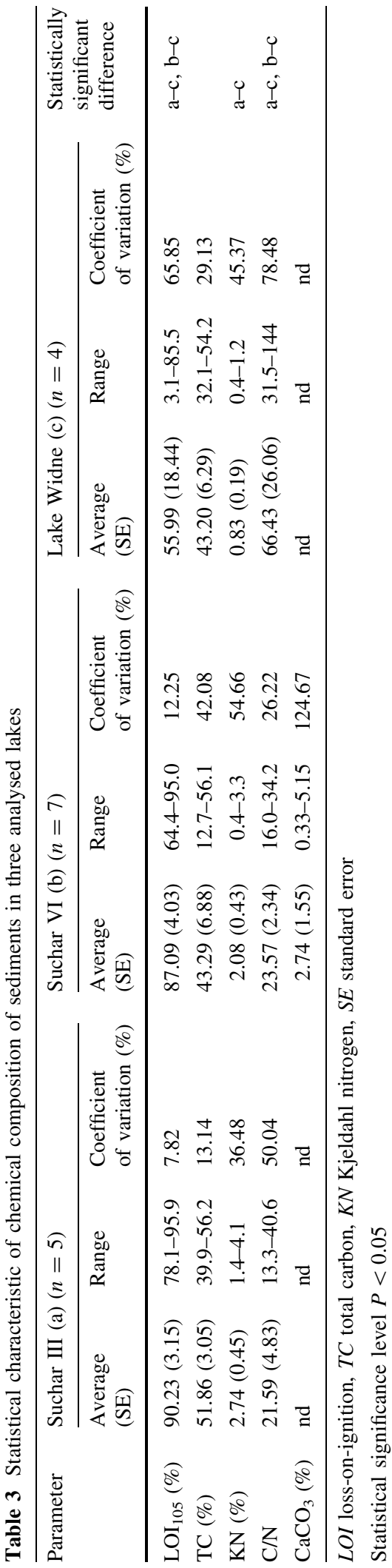

were more frequent among them-especially in the SVI core (Fig. 3).

Two radiocarbon dates were obtained for each core (Table 2). The age of bottom sediments was as follows: 13075-12700 cal BP for SVI; 10115-9670 cal BP for SIII and 8747-8479 cal BP for JW. In the SIII profile, poor fen Sphagnum peat and Sphagnum peat were recognized (Fig. 2), as well as three main plant macrofossil zones (Fig. 2; Table 4). Peat is strongly and slightly decomposed (Fig. 2). In the SVI profile, brown moss peat and poor fen Sphagnum peat were described (Fig. 3). Two main plant macrofossil zones were recognized (Table 5). Degree of peat decomposition achieves different values (Fig. 3). In the JW core, poor fen Sphagnum peat, sedge-reed peat and sedgeSphagnum peat were noted (Fig. 4), as well as three plant macrofossil zones (Fig. 4; Table 6). Peat is medium and strongly decomposed, mainly (Fig. 4).

The ages of the poor fen Sphagnum peat identified in the SVI and JW profiles were different. At SVI, this peat started to form before 9915-9635 cal BP, whereas the poor fen Sphagnum peat by Lake Widne was deposited during the youngest, contemporary phase of mire formation (1955-1957 cal AD). The roof part of the deposit at the SIII mire was also young (1435-1615 cal AD).The accumulation rates were different within each profile (Figs. 2, 3, 4), but the lowest average accumulation rate was noted in the JW profile $(0.1 \mathrm{~mm} /$ year $)$.

The succession of subfossil plant communities differed in each of the areas studied. Only in the mire of SIII, bog vegetation with Sphagnum magellanicum and Sphagnum fallax was noted. Whereas reedswamp vegetation typical for eutrophic lakes occurred only by JW. The following sequences of subfossil plant communities were identified:

SIII: peat moss communities of poor fen (SIII-1 zone; in the Boreal period) $\rightarrow$ peat moss communities of bog (SIII-2 and SIII-3 zones; in the subatlantic period)

SVI: brown moss communities of moderately rich fen (SVI-1 zone; in the Younger Dryas) $\rightarrow$ peat moss communities of poor fen (SVI-2 zone; in the Boreal period)

JW: sedge-peat moss communities of moderately rich fen (JW-1 zone; in the Atlantic period) $\rightarrow$ reedswamp vegetation (JW-2 zone; in the subboreal period) $\rightarrow$ sedge-peat moss communities of moderately rich fen (JW-3 zone; a few last decades ago) 
Table 4 Description of plant macrofossil zones of SIII profile

\begin{tabular}{|c|c|c|}
\hline Zone & Depth $(\mathrm{cm})$ & Description \\
\hline SIII-3 & $0-20$ & $\begin{array}{l}\text { The last, top zone is characterized by the dominance of Sphagnum fallax (over } 80 \% \text { ). } \\
\text { Remains of Sphagnum magellanicum (max. } 25 \% \text { ), rootlets of Ericaceae (max. } 5 \% \text { ), } \\
\text { periderm of Pinus sylvestris (max. } 5 \% \text { ) and brown mosses remains (minimal amount) are } \\
\text { present. }\end{array}$ \\
\hline $\begin{array}{l}\text { SIII-2 (SIII-2c, } \\
\text { SIII-2b, SIII-2a) }\end{array}$ & $20-180$ & $\begin{array}{l}\text { Remains of Sphagnum magellanicum dominate (max. } 90 \% \text { ). Sphagnum fallax reaches } \\
25 \% \text {. Rootlets of Ericaceae, epiderm of Eriophorum vaginatum, periderm of Pinus } \\
\text { sylvestris and brown mosses are recorded in lower percentage. }\end{array}$ \\
\hline SIII-1 & $500-570$ & $\begin{array}{l}\text { The variability of macrofossils in this zone is considerable. Sphagnum subsecundum (max. } \\
30 \% \text { ), Sphagnum palustre (max. } 40 \% \text { ), and Sphagnum obtusum (max. } 15 \% \text { ) dominate. } \\
\text { Sphagnum contortum, Sphagnum teres, Sphagnum cuspidatum, Sphagnum fallax, and } \\
\text { peat mosses of Acutifolia section are present, as well as periderm of Pinus sylvestris, } \\
\text { coniferous wood, radicles of Carex, Carex cf. limosa, and remains of brown mosses }\end{array}$ \\
\hline
\end{tabular}

Table 5 Description of plant macrofossil zones of SVI profile

\begin{tabular}{|c|c|c|}
\hline Zone & $\begin{array}{l}\text { Depth } \\
(\mathrm{cm})\end{array}$ & Description \\
\hline $\begin{array}{l}\text { SVI-2 (SVI-2f, SVI-2e, SVI-2d, } \\
\text { SVI-2c, SVI-2b, SVI-2a) }\end{array}$ & $0-550$ & $\begin{array}{l}\text { This zone is characterized by dominance of Sphagnum subsecundum (max. } 40 \% \text { ) } \\
\text { and Sphagnum palustre (max. } 50 \% \text { ). Periderm of Pinus sylvestris and rootlets of } \\
\text { Ericaceae (Andromeda polifolia, Vaccinium oxycoccos) comprise even } 25 \text { and } \\
20 \% \text { of the sediment volume, respectively. Sphagnum obtusum, Sphagnum } \\
\text { contortum, Sphagnum teres, Sphagnum cuspidatum, Sphagnum fallax are } \\
\text { present. Birch is represented by fruits (Betula sec. Albae) }\end{array}$ \\
\hline SVI-1 & $640-680$ & $\begin{array}{l}\text { Brown mosses comprise even } 100 \% \text { of the sediment volume. Remains of } \\
\text { Calliergon giganteum (max. } 50 \% \text { ), Helodium blandowii (max. } 40 \% \text { ), } \\
\text { Drepanocladus aduncus (max. } 15 \% \text { ), Aulacomnium palustre (max. } 30 \% \text { ) are } \\
\text { recorded. Remains of Pinus sylvestris, peat mosses, roots of Ericaceae, and } \\
\text { coniferous wood are represented in small amount }\end{array}$ \\
\hline
\end{tabular}

\section{Sediment chemistry}

The organic carbon content of the profiles studied ranged from $12.7 \%$ in SVI to $56 \%$ in SIII (Table 3). The highest variability of this parameter was noted in the SVI profile, where the coefficient of variability was $\mathrm{CV}=42 \%$. The value of this coefficient in the SIII and JW cores was distinctly lower (Table 3). No statistically significant differences were noted in organic carbon content or loss-on-ignition when the three profiles were compared (Table 3). Statistically significant differences were noted for KN between the SIII and JW profiles, but not between the SVI and SIII or SVI and JW profiles (Table 3). The $\mathrm{C} / \mathrm{N}$ ratio differed quite substantially among the three profiles studied, and statistically significant differences $(P<0.05)$ of the $\mathrm{C} / \mathrm{N}$ ratio were noted between JW and the other two profiles. Specifically, the $\mathrm{C} / \mathrm{N}$ ratio in the JW profile was almost three times higher than in the SIII and SVI profiles, while there were no statistically significant differences between SIII and SVI. $\mathrm{CaCO}_{3}$ was only noted in the bottom samples below $6.5 \mathrm{~m}$ of the SVI core. The maximum content of calcium carbonate in this profile was $5.2 \%$ at a depth of $6.8 \mathrm{~m}$.

The discriminant analysis of the chemical composition of the sediments of the three profiles indicated similarity between SIII and SVI sediments, which are both different from the JW core (Fig. 5).

\section{Lake water chemistry}

The physicochemical parameters of the waters in the three lakes studied indicated distinct differentiation: in SIII, the waters were the most acidic, ion poor and the richest in organic matter, what is indicated by the highest values of COD (Table 7); in JW, the waters were the least acidic, the richest in calcium ions, and 
Table 6 Description of plant macrofossil zones of JW profile

\begin{tabular}{|c|c|c|}
\hline Zone & Depth $(\mathrm{cm})$ & Description \\
\hline JW-3 & $0-10$ & $\begin{array}{l}\text { Sphagnum teres reaches } 30 \% \text {. Sphagnum subsecundum, Sphagnum squarrosum, Sphagnum } \\
\text { palustre are noted. Vascular plants are represented by: rhizoderm and roots of Equisetum } \\
\text { limosum, remains of Thelypteris palustris, and radicles of Carex. }\end{array}$ \\
\hline JW-2 & $10-50$ & $\begin{array}{l}\text { This zone is characterized by dominance of Carex radicles (Carex sp.-max. } 60 \% \text { ). Radicles } \\
\text { of Carex cf. rostrata achieve } 20 \% \text {. Epiderm of Phragmites australis comprise even } 20 \% \text { of } \\
\text { sediment volume. Rizoderm and roots of Equisetum limosum, roots of Cladium mariscus and } \\
\text { epiderm of Eriophorum cf. angustifolium are recorded. }\end{array}$ \\
\hline JW-1 & $50-90$ & $\begin{array}{l}\text { Radicles of Carex and remains of peat mosses dominate. Sphagnum teres achieves even } 35 \% \text {. } \\
\text { Sphagnum subsecundum, and Sphagnum palustre comprise } 20 \% \text {, and } 25 \% \text { of the sediment } \\
\text { volume, respectively. Radicles of Carex cf. limosa, rhizoderm of Equisetum limosum, } \\
\text { periderm of Pinus sylvestris and coniferous wood are present. }\end{array}$ \\
\hline
\end{tabular}

Fig. 5 Discriminant analysis of chemical sediments parameters of studied

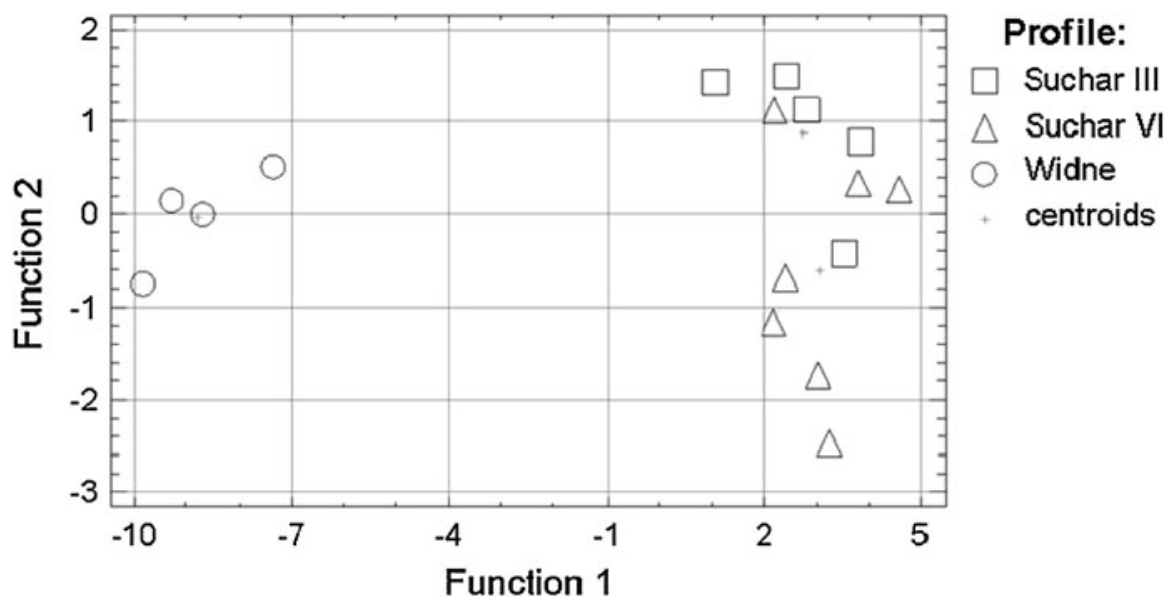

the poorest in organic matter; in SVI, the parameters were of intermediate values (Table 7).

\section{Contemporary vegetation}

Detrended correspondence analysis of the vegetation of the lake-mire systems (Fig. 6) resulted in five distinct clusters:

I. species-poor nympheid vegetation of the Potametea class (Potametum natantis with Potamogeton natans and Nymphaea alba);

II. species-poor bladderwort- and moss-dominated water vegetation of the Utricularietea intermedio-minoris class (Sphagno-Utricularietum minoris with Sphagnum cuspidatum, Warnstorfia fluitans and Utricularia minor);

III. reedswamp vegetation of the Phragmitetea class typical of littoral zones of meso- and eutrophic lakes (Thelypteridi-Phragmitetum with Thelypteris palustris, Calliergonella cuspidata and Menyanthes trifoliata) and moderately species-rich fen vegetation of the Scheuchzerio-Caricetea nigrae class typical of moderately rich fens (with moderately calcitolerant species, e.g. Sphagnum subsecundum, Carex lasiocarpa, Comarum palustre and Calliergon stramineum);

IV. calcifuge Sphagnum-dominated mires including both quaking poor fens of the "acidic wing" of the Scheuchzerio-Caricetea nigrae class (with Sphagnum angustifolium, Sph. fallax, Scheuchzeria palustris, Oxycoccus palustris and Menyanthes trifoliata) and firm (non-quaking) boglike vegetation of the Oxycocco-Sphagnetea class (Eriophoro vaginati-Sphagnetum recurvi with Sphagnum angustifolium, Sph. fallax, Eriophorum vaginatum and Oxycoccus palustris);

$\mathrm{V}$. pine woodlands of the Vaccinio-Piceetea class (Vaccinio uliginosi-Pinetum with Pinus 
Table 7 Chemical parameters of water in three investigated lakes

\begin{tabular}{lllllll}
\hline Lake & $\mathrm{pH}$ & $\mathrm{EC}\left[\mu \mathrm{s} \mathrm{cm}^{-1}\right]$ & $\mathrm{COD}-\mathrm{KMnO}_{4}$ & $\mathrm{Ca}^{2+}\left[\mathrm{mg}\left(\mathrm{dm}^{3}\right)^{-1}\right]$ & $\mathrm{Mg}^{2+}\left[\mathrm{mg}_{\left.\left(\mathrm{dm}^{3}\right)^{-1}\right]}\right.$ & $\mathrm{Fe}_{\text {og. }}\left[\mathrm{mg}\left(\mathrm{dm}^{3}\right)^{-1}\right]$ \\
\hline Suchar III & 4.60 & 20.0 & 17.23 & 0.5 & 0.36 & 0.25 \\
Suchar VI & 5.92 & 19.1 & 6.29 & 3.4 & 0.62 & 1.03 \\
Lake Widne & 6.78 & 33.7 & 5.10 & 3.7 & 0.99 & 1.88 \\
\hline
\end{tabular}

Fig. 6 Detrended correspondence analysis (DCA) of vegetation relevés from all vegetation zones in three lake-mire systems. Eigenvalues: $\lambda_{1}=0.967$ $\lambda_{2}=0.468 ; \lambda_{3}=0.275$; $\lambda_{4}=0.173$. Roman numerals denote distinguished vegetation types (see explanation in text)

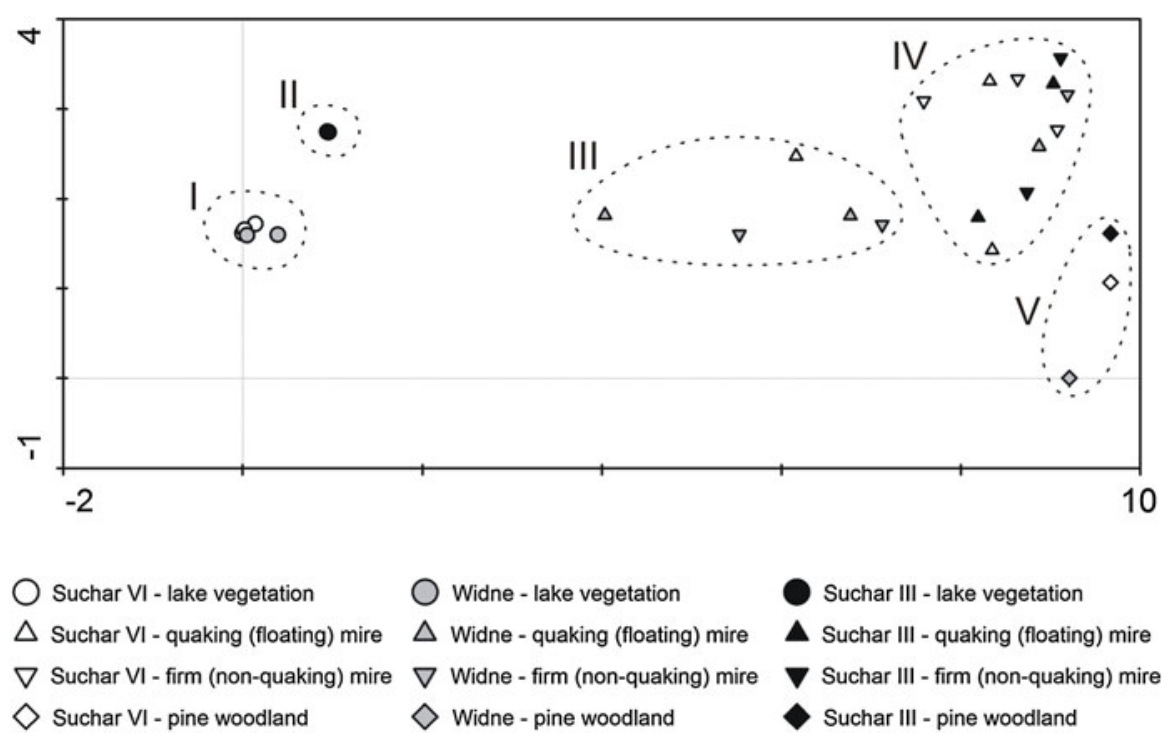

sylvestris, Sphagnum fallax, Sph. magellanicum, Pleurozium schreberi and Ledum palustre).

The greatest differences between the vegetation of the lakes were documented in the aquatic and shore zones. Lake vegetation with calcifuge mosses and Utricularia (cluster II) occured only in SIII, where there is no aquatic or rush vegetation typical of mesotrophic or eutrophic lakes. Non-acidic aquatic vegetation (I) and rushes typical of mesotrophic and eutrophic lakes, as well as mire vegetation typical of moderately rich fens (III), occur only at SVI and JW. The subsequent zones of lake overgrowing were very similar for each of the lakes studied and comprised acidic Sphagnum mires (IV) and pine woodlands (V), which were located by all the three lakes. The woodless acidic Sphagnum mires (IV) formed a continuous zone around SIII, whereas they were superseded in places by mire vegetation with brown mosses (III) by SVI and JW.

\section{Discussion}

Development of foreshore mires

Despite their close proximity to one another and location in the same climatic zone, three humic lakes have developed differently. The accumulation of dy sediment in the foreshore of SVI, in the younger half of the Alleröd (13075-12700 cal BP) (Fig. 3), could have been initiated by rising groundwater levels in the vicinity of the water body, as was also noted in nearby Lake Wigry, based on an analysis of Cladocera subfossils (Zawisza \& Szeroczyńska, 2007). Climate warming in the late glacial interstadials caused the gradual melting of ground ice blocks filling depressions. The slowly disappearing permafrost led to free ground water circulation and calcium being carried away from leaching glacial deposits (Żurek, 2000), which could explain the occurrence of the slight 
amount of $\mathrm{CaCO}_{3}$ in the SVI profile below $6.5 \mathrm{~m}$ (Fig. 3). The accumulation rate of sediments in the lower part of the SVI core was high $(0.88 \mathrm{~mm} /$ year $)$, probably because of the presence of lacustrine sediment in the profile. Thus, peat accumulation on the SVI foreshore probably began in the Younger Dryas (SVI-1 zone), and the foreshore zone was occupied by strongly inundated brown moss communities of moderately rich fen, with species such as Calliergon giganteum, Drepanocladus aduncus s.l. and Helodium blandowii, as was confirmed by well-preserved peat components (Fig. 3).

In the nearby SIII, dy sediments did not begin to accumulate until the first half of the Boreal period (10115-9670 cal BP) (Fig. 2), which could have resulted from the high-water level in basin, similar to that noted in Lake Wigry (Zawisza \& Szeroczyńska, 2007; Staniszewska \& Namiotko, 2009). In contrast, data from this region of Poland indicate that the water levels of lakes and mires were quite low at the beginning of the Boreal period (Starkel, 2006). Thus, changes in water levels cannot be assumed to have been climatically driven, otherwise they would have been regionally synchronous (Harrison \& Digerfeldt, 1993). Changes in lake levels must be assumed to have been driven by various local factors, such as geology or changes in catchment area after any disturbances (Magny, 2001).

The oldest peat layer, described in the SIII foreshore, indicated that peat moss communities of poor fen (SIII-1) (Fig. 2) occurred there. Sphagnum subsecundum and Sphagnum palustre dominated, like in the SVI location. Sphagnum obtusum, Sphanum contortum, sedges and even peat moss species of the Acutifolia section, typical for bogs, were also present.

Peat accumulation near JW began in the first half of the Atlantic period (8615-8505 cal BP) (Fig. 4). Poor fen Sphagnum peat accumulated directly on the mineral substratum in the JW-1 zone. It was formed by sedge-peat moss community of moderately rich fen with Sphagnum teres, Sphagnum subsecundum, Sphagnum palustre and Carex limosa. High-water levels were noted in contemporary mires and lakes including Lake Wigry (Zawisza \& Szeroczyńska, 2007); however, no lacustrine sediments were noted in the JW foreshore.

The stratigraphic differences between the three lakes studied suggest that autogenic processes and local topography were more significant in shaping the development of these lakes than the regional climatic and hydrological changes. The divergences in the timing of foreshore mire development could have resulted from the differences in the size and depth of the lakes and their morphometry. According to Anderson et al. (2003), smaller lakes overgrow more quickly. SVI is the smallest of the lakes studied, and its sediments are the oldest.

The mires in the vicinity of lakes SIII and SVI were clearly formed in a lacustrine environment at the borderline of limnicum and terrestricum, and it is often impossible to classify sediments accumulated under such conditions. Only microscopic analysis permits differentiation between peat and lacustrine sediments (Kowalewski \& Barabach, 2010).

The telmatic character of the environment in the vicinity of the SIII and SVI cores was confirmed by the higher amounts of nitrogen in the sediments of these cores than in those from the foreshore of Lake Widne. Organic matter of lacustrine origin is a source of nitrogen, and the sediments from the SIII and SVI cores have abundant cladoceran remains and Nymphaeaceae tissues. The $\mathrm{C} / \mathrm{N}$ parameter is used to determine the domination of autogenic or allogenic sources of organic matter in sediments. The $\mathrm{C} / \mathrm{N}$ ratio for aquatic plants, phytoplankton and zooplankton is 10 or below, whereas that for terrestrial plants exceeds 10 and can be as high as 45-50 (Meyers, 1994; Ji et al., 2005). Aquatic organisms, such as algae, phytoplankton and zooplankton contain large amount of protein, hence the $\mathrm{C} / \mathrm{N}$ ratio is low (Krishnamurthy et al., 1986). The sediments from the JW core comprise fen peat (sedge-reed peat; JW-2) (Fig. 4) of dense consistency formed by peat mosses, sedges, reed and other emergent plants. The highest value of the $\mathrm{C} / \mathrm{N}$ ratio in the profiles studied was noted in the JW core, and this suggests a higher proportion of terrestrial organic matter in the sediments, especially those of reedswamp origin (Table 3). The presence of peat remains of Phragmites australis, Carex cf. rostrata, Carex cf. elata, Cladium mariscus confirm that (JW-2; Fig. 4) the $\mathrm{C} / \mathrm{N}$ parameter is three times higher than that in the SIII and SVI profiles. Pokorny (2001) reported a similar interpretation of high values of $\mathrm{C} / \mathrm{N}$ ratios.

The rate of peat accumulation in the JW core (0.1 mm/year; Fig. 4) was very low even for fen peat (Żurek, 1986). The reason was probably strong peat 
decomposition caused by fluctuations in groundwater levels in the vicinity of the lake. No reedswamp vegetation was identified at the foreshore of SIII or SVI in the past. Peat moss communities typical of acid-poor fens were noted on the lakeshore of SVI from the Boreal period (9915-9635 cal BP; SVI-2) (Fig. 3). Sphagnum subsecundum and Sphagnum palustre dominated. Ericaceae dwarf shrubs, brown mosses, peat mosses of Cuspidata section and Scheuchzeria palustris accompanied them. Tree (Betula sec. Albae) and shrub birches (Betula cf. humilis) occurred probably directly at mire. At SIII, an oligotrophic bog developed (515-335 cal BP; SIII-2) (Fig. 2). Sphagnum magellanicum was the dominant species, but Sphagnum fallax replaced it in the last phase of mire development. The accumulation rate of bog Sphagnum peat in the SIII profile was high at $2.66 \mathrm{~mm} /$ year (Fig. 2). This value is similar to the values noted for the Jelenia Wyspa mire (the Tuchola Forest) for Sphagnum peat (Lamentowicz et al., 2007). The lithology of the SIII and SVI cores indicated that the floating mats of these lakes were better developed than those of JW, which was probably due to hydrological changes in the vicinity of both of these lakes (i.e. the presence of water gaps and dy layers). Floating mat developed in the JW foreshore just only in the last phase of the mire development (see subsection below).

\section{Present vs. past vegetation}

Differences in contemporary plant communities are reflected in the subfossil vegetation at each of the lakes studied. The surroundings of SIII, which possesses the most distinct attributes of the humic state, were previously overgrown by plant communities of poor fen and bog vegetation with Sphagnum magellanicum and Sphagnum fallax. Both species are still important at this location. The foreshore of SVI was, at least from the Boreal period, dominated by poor fen communities, and the current dominant plant associations are also typical of this kind of mire. Peat mosses of the Subsecunda section (Sphagnum subsecundum, Sphagnum contortum) were important species in the subfossil communities, as were Sphagnum palustre and representatives of the Cuspidata section (Sphagnum obtusum, Sphagnum cuspidatum). The highest abundance of mineral matter was noted in JW. Currently, typical nympheid, reedswamp and moderately rich fen vegetation occupy the waters and shores of this lake. Previously, there was no bog vegetation, but there was vegetation typical of moderately rich and rich fens with Carex cf. rostrata, Phragmites australis and Equisetum limosum. The atypical floating mat of Thelypteris palustris, Sphagnum teres and Sphagnum subsecundum started to develop only about 50 years ago (1955-1957 cal AD) (Fig. 4). Sphagnum teres currently remains the important peat moss at the foreshore of this lake.

The dissimilarity of JW with regard to vegetation and the chemical parameters of both sediments and waters might stem from calcium inflow and/or low ratio of catchment area to lake area, which was approximately nine times smaller than that of SIII, and this indicates that the catchment area had a low impact on JW (Table 1). The character of its catchment area is also different. The catchment area of SIII is typically forested, while that of JW is pasture, forested and agricultural. As we know, catchment areas have a fundamental impact on the functioning of humic lakes (De Haan, 1992; Hessen, 1992; Hessen \& Tranvik, 1998). It is likely that the JW catchment was never significantly natural afforested and possible afforestation in the future (both forest plantations and natural secondary forest regeneration) could push the trophic status of the lake towards that of more typical for humic lake, like SIII. Thus, it can be concluded that approximately neutral $\mathrm{pH}$ and $\mathrm{EC}$ values exceeding $30 \mu \mathrm{S} \mathrm{cm}^{-1}$, which were noted in JW (Table 7), ranks this water body near the limit line of the humic lake category.

The studied lakes classified as humic that are located in the same vicinity vary both with regard to their foreshore vegetation (floating Sphagnum mats or reedswamp and moderately rich fen vegetation) and hydrochemical parameters $(\mathrm{pH}, \mathrm{DOM}$, calcium ion content). We recognized that each of these water bodies changed over time but only in the precise, restricted range, determined by the abundance of mineral substances in lake. For this reason, in the SIII site only poor fen and bog could develop. At the SVI foreshore, there were both poor fens and moderately rich fens in the past but bog vegetation was absent, while communities of moderately rich and even rich fens occupied the JW site. Contemporary vegetation corresponds to recent subfossil plant communities at every foreshore.

Expectations for the future of humic lakes are uncertain. On the one hand, we could assume that these 
water bodies could transform into less humic ones. Climate changes observed in the late 20th century, e.g. in northeastern Poland, like winter warming, short snow cover and predominance of dry springs, cause changes of habitats to conditions less favourable for humic waters. As we know humic lakes are mainly associated with cool and humid climates (Salonen et al., 1983; Kankaala et al., 2006). On the other hand, perhaps the unintended rescue for these ecosystems would be intensive export of DOM to surface waters observed recently in Europe and North America (Freeman et al., 2001; Roulet \& Moore, 2006). If this phenomenon is correct, this would have very different implications, as it implies that acid-sensitive waters are simply recovering towards their higher organic matter content, due to their pre-industrial state as sulphur deposition declines (Evans et al., 2006, 2012).

Humic or not?

Using the evidence described above, we can now consider whether the lakes studied should be classified as humic, and just where the border of humic/not humic lake is. The current research indicated that lakes could be described as humic if aquatic and shore vegetation is related to Sphagnum-dominated quaking mires, and the hydrochemical parameters of water (high content of humic substances, low $\mathrm{pH}$, low concentrations of $\mathrm{Ca}$, $\mathrm{Mg}$, etc.) are typical of humic lakes. High concentrations of acidic humic matter and low $\mathrm{pH}$ eliminate submerged macrophytes (Farmer, 1990; Szmeja \& Bociagg, 2004). Thus, in humic lakes macrophytes consist almost exclusively of nympheids, and in the most acidic lakes macrophytes are absent (Gąbka et al., 2004). Studies by Sobotka (1967) and Gąbka et al. (2004) showed that, in Poland, nympheids occur in humic lakes. Thus, the presence of nympheids, like Nymphaea sp., Nuphar lutea or Potamogeton natans, could place any lake in the humic lake category.

Thus, in our opinion, JW does not possess all attributes of humic lake, because:

- the water $\mathrm{pH}$ was about neutral;

- the values of $\mathrm{COD}-\mathrm{KMnO}_{4}$ were low, which indicates the presence of a small amount of DOM and, indirectly, of humic acids;

- the ion concentration, including $\mathrm{Ca}^{2+}$, was higher than in the other two lakes; $\mathrm{pH}$ values were buffered further by the carbonate complex;
- at the foreshore and in the water reedswamp and moderately rich fen plant communities were found; the same vegetation was also noted in the past.

Higher water $\mathrm{pH}$ values noted in lakes classified as humic could result from anthropogenic or natural eutrophication (Chmiel, 2009); however, we concluded that the quite high-water $\mathrm{pH}$ value in JW could have occurred since its formation. According to Górniak (2006), in 1986-2002, the water $\mathrm{pH}$ values ranged from 6.2 to 7.2 in $\mathrm{JW}$, whereas in SIII they were at 3.9-6.6. Thus, the conditions in SIII were highly variable within although highly acidic. SVI occupied an intermediate position with a water $\mathrm{pH}$ of 6-6.8 in 1986-2002 and pH of 4.4 in 1971.

The Humic State Index (HSI) (Håkanson \& Boulion, 2001) and the Hydrochemical Dystrophy Index (HDI) are used to measure the trophic status of lakes (Górniak, 2006). Humic lakes have HDI values higher than 50. According to Górniak (2006), the HDI values recorded for lakes SIII, SVI and JW in 2002 were 121.0, 63.5 and 64.3, respectively. However, Chmiel (2009), who investigated the trophic state of lakes in southeastern Poland, did not classify any of the lakes investigated as humic even though HDI values periodically exceeded 50 , because this parameter was unstable.

Consequently, we believe that HDI values insignificantly exceeding 50 are insufficient for describing any lake as humic. Lakes JW and SVI investigated in the current study were characterized by quite low-HDI values and their hydroseral vegetation was typical of eutrophic lakes and moderately rich fens. These features in combination with the approximately neutral water $\mathrm{pH}$ indicated that the lakes were not typical humic lakes (suchary).

Górniak (2006), Chmiel (2009) and Zielinski et al. (2011) used name "humoeutrophic lake" for few atypical humic lakes from Poland. In Estonia, Sweden and Finland, lakes called dystrophic (humic), semidystrophic and dyseutrophic were recognized on the basis of water transparency (Arst \& Reinart, 2009). Klavins et al. (2003) recognized, among Latvian lakes, dystrophic and dyseutrophic water bodies. The latter were characterized by higher $\mathrm{pH}$ values. Among Norwegian humic lakes moderately humic water bodies, with total organic carbon (TOC) up to $15 \mathrm{mg} / \mathrm{l}$, were recognized (Brakke et al., 1987). 
According to Williamson et al. (1999), these atypical humic lakes should be named "mixotrophic lakes," which suggests their position on the border between dystrophy and eutrophy (Nürnberg \& Show, 1998). These conclusions correspond with the findings of Gąbka \& Owsianny (2006) and the "Interpretation Manual of European Union Habitats" (Anonymous, 2007), in which humic lakes are described as having a water $\mathrm{pH}$ of less than 6 .

It is clear that the occurrence of lakes of uncertain humic status is a result of intermediate values of environmental factors. We propose classifying lakes with floating mire, a water $\mathrm{pH}$ approximately neutral, with low concentrations of mineral matter (low-EC values) and reedswamp in the marginal parts of floating mats (but without Chara communities or isoetids) as special forms of the natural dystrophic lakes and ponds habitat, which is protected in the EU by the Water Habitat Directive (Anonymous, 2007).

Acknowledgments This research was financed by the Ministry of Science and Higher Education in Poland, project no. NN305085135 "History of dystrophic lakes of the Wigry National Park in the light of the Holocene succession of their vegetation." The authors would like to thank the anonymous reviewers for their comprehensive reading of the manuscript and constructive suggestions for its improvement.

Open Access This article is distributed under the terms of the Creative Commons Attribution License which permits any use, distribution, and reproduction in any medium, provided the original author(s) and the source are credited.

\section{References}

Allison, L. E. \& C. D. Moodie, 1965. Carbonate volumetric calcimeter method. In Black, C. A. (ed.), Methods of Analysis. Agronomy Monograph. No. 9. Part 2. American Society of Agronomy, Madison, WI: 1389-1392.

Anderson, R. L., D. R. Foster \& G. Motzkin, 2003. Integrating lateral expansion into models of peatland development in temperate New England. Journal of Ecology 91: 68-76.

Anonymous, 2007. Interpretation Manual of European Union Habitats-EUR 27. European Commission DG Environment.

Arst, H. \& A. Reinart, 2009. Application of optical classifications to North European lakes. Aquatic Ecology 43: 789-801.

Ber, A., 2009. Budowa geologiczna, geomorfologia i geneza obrzeżenia jeziora Wigry w nawiązaniu do struktur głębokiego podłoża [The Wigry lake surroundings geology, geomorphology and origin against tectonic structures of the deep basement]. In Rutkowski, J. \& L. Krzysztofiak (eds), Jezioro Wigry. Historia jeziora w świetle badań geologicznych i paleoekologicznych [Wigry Lake. History of the Lake in the Light of Geological and Palaeoecological Studies]. Stowarzyszenie Człowiek i Przyroda, Suwałki: 13-30 (in Polish).

Brakke, D., A. Henriksen \& S. A. Norton, 1987. The relative importance of acidity sources for humic lakes in Norway. Nature 329: 432-434.

Braun-Blanquet, J., 1951. Pflanzensoziologie (Phytosociology). 2 Aufl. Springer, Wien (in German).

Bremner, J. M. \& C. S. Mulvaney, 1982. Nitrogen-total. In Page, A. L. (ed.), Methods of Soil Analysis. Agronomy No. 9. American Society of Agronomy, Madison, WI: 595-624.

Bronk Ramsey, C., 2009. Bayesian analysis of radiocarbon dates. Radiocarbon 51: 337-360.

Brönmark, C. \& L.-A. Hansson, 2005. The Biology of Lakes of Ponds, 2nd ed. Oxford University Press, New York.

Chmiel, S., 2009. Hydrochemical evaluation of dystrophy of the water bodies in the Łęczna and Włodawa area in the years 2000-2008. Limnological Review 9: 153-158.

De Haan, H., 1992. Impacts of environmental changes on the biogeochemistry of aquatic humic substances. Hydrobiologia 229: 59-71.

Evans, C. D., P. J. Chapman, J. M. Clark, D. T. Monteith \& M. S. Cresser, 2006. Alternative explanations for rising dissolved organic carbon export from organic soils. Global Change Biology 12: 2044-2053.

Evans, C. D., T. G. Jones, A. Burden, N. Ostle, P. Zieliński, M. D. A. Cooper, M. Peacock, J. M. Clark, F. Oulehle, D. Cooper \& C. Freeman, 2012. Acidity controls on dissolved organic carbon mobility in organic soils. Global Change Biology. doi:10.1111/j.1365-2486.2012.02794.x.

Farmer, A., 1990. The effects of lake acidification on aquatic macrophytes - a review. Environmental Pollution 65: 219-240.

Freeman, C., S. D. Evans, B. Monteith, B. Reynolds \& N. Fenner, 2001. Export of organic carbon from peat soils. Nature 412: 785.

Gąbka, M. \& P. Owsianny, 2006. Shallow humic lakes of the Wielkopolska region - relation between dystrophy and eutrophy in lake ecosystems. Limnological Review 6: 95-102.

Gąbka, M., P. Owsianny \& T. Sobczyński, 2004. Acidic lakes in the Wielkopolska region - physico-chemical properties of water, bottom sediments and the aquatic micro- and macrovegetation. Limnological Review 4: 81-88.

Górniak, A., 2006. Typologia i aktualna trofia jezior WPN (Typology and present trophy of lakes). In Górniak, A. (ed.), Jeziora Wigierskiego Parku Narodowego (Lakes of the Wigry National Park). Wydawnictwo Uniwersytetu w Białymstoku, Białystok: 128-140 (in Polish).

Górniak, A., E. Jekatierynczuk-Rudczyk \& P. Dobrzyń, 1999. Hydrochemistry of three dystrophic lakes in Northeastern Poland. Acta Hydrochimica et Hydrobiologica 27: 12-18.

Håkanson, L. \& V. V. Boulion, 2001. Regularities in primary production, Secchi depth and fish yield and a new system to define trophic and humic state indices for lake ecosystems. International Review of Hydrobiology 86: 23-62.

Harrison, S. P. \& G. Digerfeldt, 1993. European lakes as palaeohydrological and palaeoclimatic indicators. Quaternary Science Reviews 12: 233-248. 
Hedenäs, L., 2003. The European species of the CalliergonScorpidium-Drepanocladus complex, including some related or similar species. Meylania 28: 1-117.

Hermanowicz, W., W. Dożańska, J. Dojlido \& B. Koziorowski, 1999. Fizyczno-chemiczne badanie wody i ścieków (Physical-Chemical Research of Water and Effluents). Arkady, Warszawa (in Polish).

Hessen, D., 1992. Dissolved organic carbon in a humic lake: effects on bacterial production and respiration. Hydrobiology 229: 115-123.

Hessen, D. O. \& L. J. Tranvik, 1998. Aquatic Humic Substances. Ecology and Biogeochemistry. Springer, Berlin.

Howard, P. J. A. \& D. M. Howard, 1990. Use of organic carbon and loss-on-ignition to estimate soil organic matter in different soil types and horizons. Biology and Fertility of Soils 9: 306-310.

Hutorowicz, A., E. Szeląg-Wasilewska, M. Grabowska, P. M. Owsianny, W. Pęczuła \& M. Luścińska, 2006. Występowanie Gonyostomum semen (Raphidophyceae) w Polsce (Occurrence of Gonyostomum semen (Raphidophyceae) in Poland). Fragmenta Floristica et Geobotanica Polonica 13: 399-407. (in Polish).

Ji, S., L. Xingqi, W. Sumin \& R. Matsumoto, 2005. Palaeoclimatic changes in the Qinghai Lake area during the last 18,000 years. Quaternary International 136: 131-140.

Kankaala, P., J. Huotari, E. Peltomaa, T. Saloranta \& A. Ojala, 2006. Methanotrophic activity in relation to methane efflux and total heterotrophic bacterial production in a stratified, humic, boreal lake. Limnology and Oceanography 46: 1195-1204.

Katz, N. J., S. W. Katz \& M. G. Kipiani, 1965. Atlas i oprjedielitjel plodov i semian vstreczajuszczychsia v czetvjerticznych odlozeniach SSSR (Atlas and Key of Fruits and Seeds from Quaternary Sediments of USSR). Nauka, Moskwa. (in Russian).

Kilian, M. R., B. van Geel \& J. van der Plicht, 2000. ${ }^{14}$ C AMS wiggle matching of raised bog deposits and models of peat accumulation. Quaternary Science Reviews 19: 1011-1033.

Klavins, M., V. Rodinov \& I. Druvietis, 2003. Aquatic chemistry and humic substances in bog lakes in Latvia. Boreal Environment Research 8: 113-123.

Kondracki, J., 1994. Geografia Polski. Mezoregiony fizycznogeograficzne (Geography of Poland. Physical-Geographical Regions). PWN, Warszawa (in Polish).

Kowalewski, G. \& J. Barabach, 2010. Struktura osadów zbiornika jeziorno-torfowiskowego Dury V (Bory Tucholskie) (Sedimentary record in lake-mire basin Dury V (Tuchola Pinewood Forest)). Studia Limnologica et Telmatologica 4: 65-74 (in Polish).

Krishnamurthy, R. V., S. K. Bhattacharya \& S. Kusumgar, 1986. Palaeoclimatic changes deduced from $13 \mathrm{C} / 12 \mathrm{C}$ and $\mathrm{C} / \mathrm{N}$ ratios of Karewa lake sediments, India. Nature 323: $150-152$.

Kullberg, A., K. H. Bishop, A. Hargeby, M. Jonson \& R. C. Petersen, 1993. The ecological significance of dissolved organic carbon in acidified water. Ambio 22: 331-337.

Lamentowicz, M., K. Tobolski \& A. D. Mitchell, 2007. Palaeoecological evidence for anthropogenic acidification of a kettle-hole peatland in northern Poland. The Holocene 17: 1185-1196.
Litt, T., A. Brauer, T. Goslar, J. Merkt, K. Bałaga, H. Müller, M. Ralska-Jasiewiczowa, M. Stebich \& J. F. W. Negendank, 2001. Correlation and synchronisation of Lateglacial continental sequences in northern central Europe based on annually laminated lacustrine sediments. Quaternary Science Reviews 20: 1233-1249.

Magny, M., 2001. Palaeohydrological changes as reflected by lake-level fluctuations in the Swiss Plateau, the Jura Mountains and the northern French Pre-Alps during the Last Glacial-Holocene transition: a regional synthesis. Global and Planetary Change 30: 85-101.

Mangerud, J., S. T. Andersen, B. E. Berglund \& J. J. Donner, 1974. Quaternary stratigraphy of Norden, a proposal for terminology and classification. Boreas 3: 109-128.

Marks, L., 2002. Last glaciation maximum in Poland. Quaternary Science Reviews 21: 103-110.

Matuszkiewicz, W., 2001. Przewodnik do oznaczania zbiorowisk roślinnych Polski (Guidebook for Determining of Plant Communities of Poland). Wydawnictwo Naukowe PWN, Warszawa (in Polish).

Mauquoy, D. \& B. van Geel, 2007. Mire and peat macros. In Elias, S. A. (ed.), Encyclopedia of Quaternary Science, Vol. 3. Elsevier Publ, Amsterdam: 2315-2336.

Meyers, P. A., 1994. Preservation of elemental and isotopic source identification of sedimentary organic matter. Chemical Geology 114: 289-302.

Mirek, Z., H. Piękoś-Mirkowa, A. Zając \& M. Zając, 2002. Flowering Plants and Pteridophytes of Poland - A Checklist. W. Szafer Institute of Botany, Polish Academy of Sciences, Kraków.

Nauman, E., 1917. Undersökning öfver phytoplankton och under den pelagiske regionen försiggående gyttja och dybildning inom vissa sydoch mellansvenska urbergsvatten (Investigation of Phytoplankton and Pelagic gyttja and dy in some Swedish Bedrock Water Bodies). Kungliga Svenska Vetenskapsakademiens Handlingar 56, Stockholm (in Swedish).

Nelson, D. W. \& L. E. Sommers, 1996. Total carbon, organic carbon, and organic matter. In Sparks, D. L., A. L. Page et al. (eds), Methods of Soil Analysis. Part 3. Chemical Methods. Agronomy Monograph. SSSA and ASA, Madison: 961-1010.

Nürnberg, G. K. \& M. Show, 1998. Productivity of clear and humic lakes: nutrients, phytoplankton, bacteria. Hydrobiologia 382: 97-112.

Obidowicz, A., 1990. Eine Pollenanalytische und Moorkundliche Studie zur Vegetationsgeschichte des Podhale-Gebietes (West-Karpaten) (Palinological and peat-science research of vegetation history of the Podhale region (Western Carpathians)). Acta Palaeobotanica 1(2): 147-219.

Ochyra, R., J. Żarnowiec \& H. Bednarek-Ochyra, 2003. Census Catalogue of Polish Mosses. W. Szafer Institute of Botany, Polish Academy of Sciences, Kraków.

Ojala, A. \& K. Salonen, 2001. Productivity of Daphnia longispina in a highly humic boreal lake. Journal of Plankton Research 23: 1207-1216.

Pokorny, P., 2001. Nutrient distribution changes within a small lake and its catchment as response to rapid climatic oscillations. In Vymazal, J. (ed.), Transformations of Nutrients in Natural and Constructed Wetlands. Backhuys Publishers, Leiden: 463-482. 
Poniewozik, M., W. Wojciechowska \& M. Solis, 2011. Dystrophy or eutrophy: phytoplankton and physicochemical parameters in the functioning of humic lakes. Oceanological and Hydrobiological Studies 40: 22-29.

Roulet, N. \& T. R. Moore, 2006. Browning the water. Nature 444: 283-284.

Rybníček, K. \& E. Rybníčková, 1974. The origin and development of waterlogged meadows in the Central Part of the Šumava Foothills. Folia Geobotanica \& Phytotaxonomica 9: 45-70.

Salonen, K., K. Kononen \& L. Arvola, 1983. Respiration of plankton in two small, polyhumic lakes. Hydrobiologia 101: $65-70$.

Sjörs, H., 1952. On the relation between vegetation and electrolytes in north Swedish mire waters. Oikos 2: 241-258.

Sobotka, D., 1967. Roślinność strefy zarastania bezodpływowych jezior Suwalszczyzny (Vegetation of the zone subject to overgrowth in endorheic lakes of the Suwałki region). Monographiae Botanicae 2: 175-258 (in Polish).

Stangenberg, M., 1936. Szkic limnologiczny na tle stosunków hydrochemicznych Pojezierza Suwalskiego (Limnological sketch with relation to hydrochemical conditions of the Suwałki Lakeland). Instytut Badawczy Leśnictwa Rozprawy i Sprawozdania A 19: 7-85 (in Polish).

Staniszewska, W. \& T. Namiotko, 2009. Ostracoda w późnoglacjalnych i holoceńskich osadach Zatoki Słupiańskiej jeziora Wigry (Late Glacial and Holocene Ostracoda from lacustrine sediments of Słupiańska Bay in Wigry Lake (NE Poland)). In Rutkowski, J. \& L. Krzysztofiak (eds), Jezioro Wigry. Historia jeziora w świetle badań geologicznych i paleoekologicznych (Wigry Lake. History of the Lake in the Light of Geological and Palaeoecological Studies). Stowarzyszenie Człowiek i Przyroda, Suwałki: 210-214 (in Polish).

Starkel, L., 2006. Problems of Holocene climatostratigraphy on the territory of Poland. Studia Quaternaria 23: 17-21.

Szmeja, J. \& K. Bociąg, 2004. The disintegration of populations of underwater plants in soft water lakes enriched with acidic organic matter. Acta Societatis Botanicorum Poloniae 73: 165-173.

Ter Braak, C. J. F. \& P. Šmilauer, 1998. CANOCO Reference Manual and User's Guide to Canoco for Windows, Software for Canonical Community Ordination (version 4).
Center for Biometry Wageningen/Microcomputer Power, Wageningen, NL/Ithaca, NY.

Thienemann, A., 1922. Biologische Seetypen und die Gründung einer hydrobiologischen Anstalt am Bodensee (Biological kinds of lakes and assignation of hydrobiological state of Lake Constance). Archiv fuer Hydrobiologie 13: 347370 .

Tołpa, S., M. Jasnowski \& A. Pałczyński, 1967. System der genetischen Klassifizierung der Torfe Mitteleuropas (System of genetic classification of peats from Middle Europe). Zeszyty Problemowe Postępów Nauk Rolniczych 79: 9-99.

Walanus, A. \& D. Nalepka, 1999. Polpal program for counting pollen grains, diagrams plotting and numerical analysis. Acta Palaeobotanica 2: 659-661.

Walanus, A. \& D. Nalepka, 2010. Calibration of Mangerud's boundaries. Radiocarbon 52: 1639-1644.

Wetzel, R. G., 1983. Limnology. W. B. Saunders Co., Philadelphia, PA.

Williamson, C. E., D. P. Morris, M. L. Pace \& O. G. Olson, 1999. Dissolved organic carbon and nutrients as regulators of lake ecosystems: resurrection of a more integrated paradigm. Limnology and Oceanography 44: 795-803.

Zawisza, E. \& K. Szeroczyńska, 2007. The development history of Wigry Lake as shown by subfossil Cladocera. Geochronometria 27: 67-74.

Zieliński, P., J. Ejsmont-Karabin, M. Grabowska \& M. Karpowicz, 2011. Ecological status of shallow Lake Gorbacz (NRE Poland) in its final stage before drying up. Oceanological et Hydrobiological Studies 40: 1-12.

Żurek, S., 1986. Szybkość akumulacji torfu i gytii w profilach torfowisk i jezior Polski (na podstawie danych 14C) (Peat and gyttja accumulation rate in profiles from mires and lakes of Poland (on the basis of ${ }^{14} \mathrm{C}$ data)). Przegląd Geograficzny 3: 459-477 (in Polish).

Żurek, S., 2000. Stratygrafia, geneza i wiek torfowiska (Stratigraphy, origin and age of mire). In Czerwiński A., A. Kołos \& B. Matowicka (eds), Przemiany siedlisk i roślinności torfowisk uroczyska Stare Biele w Puszczy Knyszyńskiej (Changes of Habitats and Vegetation of Mires from Stare Biele Range, Puszcza Knyszyńska Forest). Rozprawy Naukowe Politechniki Białostockiej 70, Białystok: 40-69 (in Polish). 